\title{
PENGARUH KUALITAS PELAYANAN TERHADAP KEPUASAN KONSUMEN LABORATORIUM KLINIK (Studi Kasus Laboratorium Klinik X Jakarta)
}

\author{
Annisa Rahadiyarsi Loekito ${ }^{1}$ *, La Diadhan Hukama² \\ ${ }^{1}$ Fakultas Ekonomi Universitas Yarsi \\ ${ }^{2}$ Fakultas Ekonomi Universitas Yarsi
}

\begin{abstract}
Abstrak
Penelitian ini bertujuan untuk menganalisis pengaruh dimensi-dimensi service quality yang bukti langsung / bukti fisik, kehandalan, daya tanggap, jaminan dan empati terhadap kepuasan konsumen Laboratorium Klinik X. Proses pengumpulan data primer dalam penelitian ini dilakukan dengan metode survei melalui pendistribusian kuesioner pada 60 konsumen. Metode penarikan sampel yang digunakan adalah nonprobability sampling. Dengan menggunakan model persamaan Analisis Regresi Linear Berganda, penelitian ini menemukan bahwa dimensi daya tanggap merupakan dimensi service quality yang memiliki pengaruh yang dominan terhadap kepuasan konsumen Laboratorium Klinik X, dibandingkan dimensi bukti fisik, jaminan dan empati. Penelitian ini juga menemukan bahwa dimensi kehandalan,memiliki pengaruh yang negatif pada kepuasan konsumen Laboratorium Klinik X.
\end{abstract}

\author{
Keywords: \\ kualitas pelayanan, daya \\ tanggap, kepuasan \\ konsumen, laboratorium \\ klinik
}

\section{PENDAHULUAN}

Saat ini, keberadaan laboratorium klinik sangat diperlukan untuk membantu menegakkan suatu diagnosa. Hasil pemeriksaan laboratorium bermanfaat bagi para klinisi untuk membantu menegakkan bahkan dapat memastikan diagnosa pasien sehingga dapat meminimalkan pengobatan / terapi yang tidak diperlukan.

Laboratorium Klinik X merupakan klinik (laboratorium medis) yang memiliki manajemen yang tangguh fasilitas, peralatan dan teknologi yang unggul serta layanan pemeriksaan yang berkualitas, ditambah kemampuan dalam melayani berbagai jenis pemeriksaan. Laboratorium Klinik X memiliki berbagai macam layanan, diantaranya adalah layanan pemeriksaan laboratorium yang menggunakan sistem mutu yang memenuhi standar mutu yang ditetapkan dengan peralatan, prosedur serta kompetensi yang dimiliki personil Laboratorium Klinik X.

Dalam rangka menjamin mutu pemeriksaan, Laboratorium Klinik X secara rutin melakukan Audit mutu, baik internal maupun eksternal yang salah satunya dilakukan oleh dilakukan oleh pihak independen yang mengacu pada standar manajemen mutu ISO 9001:2008 dan ketentuan yang ditetapkan Departemen Kesehatan RI, sehingga dijamin mampu memberikan penilaian secara obyektif. Hal tersebut dimaksudkan untuk memastikan/menjamin bahwa standar kualitas yang telah ditetapkan dapat dipertahankan di sepanjang waktu.

Berdasarkan data Laboratorium Klinik X pada Tahun 2016, bahwa pertumbuhan perusahaan berdasarkan tingkat animo pelanggan terjadi peningkatan rata-rata pertahun adalah sebesar 7.5\%. Data tersebut adalah sesuatu yang menggebirakan yang ternyata diikuti dengan peningkatan pendapatan ratarata $22.5 \%$ per tahun. Namun yang menjadi tanda tanya adalah bagaimana kepuasan konsumen terhadap layanan Laboratorium Klinik X.

Oleh karena itu, perlu diteliti faktor-faktor apa saja yang bepengaruh terhadap kepuasan konsumen Laboratorium Klinik. Untuk mengevaluasi kepuasan layanan Laboratorium Klinik X digunakan analisa deskriptif dan analisa regresi dengan dan lima aspek penentu kepuasan konsumen, yang meliputi (1) tangibles (bukti langsung) adalah penampakan fasilitas-fasilitas fisik gedung, peralatan, pegawai, dan fasilitas-fasilitas lain yang dimiliki oleh perusahaan, (2) reliability (keandalan) adalah kemampuan untuk menampilkan layanan yang dijanjikan secara andal dan akurat, (3) responsiveness (daya tanggap) adalah 
kemauan untuk menolong konsumen dan menyediakan layanan yang cepat, (4) assurance (jaminan) adalah pengetahuan dan kesopanan yang dimiliki karyawan dan kemampuan mereka untuk menyampaian rasa percaya dan kepercayaan diri kepada pelanggan, (5) empathy (empati) adalah perhatian dan kepedulian karyawan kepada konsumen secara pribadi (Parasuraman, Zeithaml, \& Berry 1988).

\section{METODE}

Populasi dalam penelitian ini adalah konsumen pengguna Laboratorium Klinik X di Jakarta Pusat. Sedangkan Metode pengambilan sampel dalam penelitian ini dilakukan dengan menggunakan metode Non Probability Sampling yaitu metode sampel yang tidak memberi kesempatan atau peluang yang sama bagi setiap unsur atau populasi untuk dipilih menjadi sampel. Sedangkan teknik penentuan sampel yang digunakan adalah sampling insidental. Sampling insidental adalah teknik penentuan sampel berdasarkan kebetulan yaitu siapa saja yang secara kebetulan / insidental bertemu dengan peneliti dapat digunakan sebagai sampel, bila dipandang orang yang kebetulan ditemui itu cocok dengan sumber data (Sugiyono, 2015).

Ukuran pengambilan sampel lebih besar dari 30 dan kurang dari 500 telah mencukupi untuk digunakan dalam penelitian. Dan apabila melakukan penelitian dengan multivariate (regresi linier berganda atau korelasi), maka jumlah anggota sampel minimal 10 kali dari jumlah variabel yang diteliti. Karena dalam penelitian ini menggunakan enam variabel ( 5 variabel independen +1 variabel dependen) maka jumlah sampel yang diperlukan sebanyak 60 .

Menurut Ghozali (2013), uji validitas digunakan untuk mengukur sah atau valid tidaknya suatu kuesioner, suatu kuesioner dikatakan valid jika pertanyaan pada kuesioner mampu untuk mengungkapkan sesuatu yang akan diukur oleh kuesioner tersebut

Suatu kuesioner dikatakan reliabel atau handal jika jawaban seseorang terhadap pertanyaan adalah konsisten atau stabil dari waktu ke waktu Ghozali, (2013). Uji reliabilitas dalam penelitian ini menggunakan teknik Cronbach Alpha $(\alpha)$, dimana suatu instrumen dapat dikatakan handal (reliabel), bila memiliki cronbach alpha $\geq 0,6$ (Santoso, 2010).

Menurut Ghazali (2013), analisis regresi linear berganda dimaksudkan untuk menguji sejauh mana arah pengaruh variabel-variabel independen terhadap variabel dependen. Variabel independen dalam penelitian ini adalah bukti langsung, keandalan, daya tanggap, jaminan dan empati dangan variabel dependen adalah kepuasan konsumen. Berikut persamaan regresi linear berganda untuk pengujian hipotesis yaitu:

$\mathrm{Y}=\mathrm{a}+\mathrm{b}_{1} \mathrm{X}_{1}+\mathrm{b}_{2} \mathrm{X}_{2}+\mathrm{b}_{3} \mathrm{X}_{3}+\mathrm{b}_{4} \mathrm{X}_{4}+\mathrm{b}_{5} \mathrm{X}_{5}+\mathrm{e}$

Dimana : $Y=$ Kepuasan Konsumen, $X_{1}=$ Bukti Fisik, $X_{2}=$ Keandalan, $X_{3}=$ Daya Tanggap, $X_{4}=$ Jaminan, $X_{5}=$ Empati, $\mathrm{a}=$ Konstanta (Intercept), $\mathrm{b}_{1}, \mathrm{~b}_{2}, \mathrm{~b}_{3}, \mathrm{~b}_{4}, \mathrm{~b}_{5},=$ Koefisien Regresi (Parameter) dan e $=$ Faktor Kesalahan

Menurut Ghozali (2013), uji t pada dasarnya menunjukkan seberapa jauh pengaruh suatu variabel bebas yang dalam hal ini bukti langsung / bukti fisik, keandalan, daya tanggap, jaminan dan empati secara parsial dapat mempengaruhi variabel terikat yaitu kepuasan konsumen.

Menurut Ghozali (2013), uji statistik F pada dasarnya menunjukkan apakah semua variabel independen atau variabel bebas yang dimasukkan dalam model mempunyai pengaruh secara bersamasama terhadap variabel dependen/terikat. Untuk melihat apakah seluruh variabel bebas yang dalam hal ini bukti langsung / bukti fisik, keandalan, daya tanggap, jaminan dan empati secara bersama-sama dapat mempengaruhi variabel terikat yaitu kepuasan konsumen.

Uji koefisien determinasi $\left(\mathrm{R}^{2}\right)$ digunakan untuk mengukur seberapa jauh kemampuan model dalam menerangkan variasi variabel bebasnya. Nilai koefisien determinasi adalah antara nol dan satu. Menurut Ghozali (2013), jika nilai $\left(\mathrm{R}^{2}\right)$ yang kecil berarti kemampuan variabel-variabel bebas dalam menjelaskan variasi variabel dependen amat terbatas. Nilai yang mendekati satu berarti variabel-variabel bebas memberikan hampir semua informasi dibutuhkan untuk memprediksi variasi variabel terikat.

\section{HASIL PENELITIAN DAN PEMBAHASAN}

Berdasarkan pengujian validitas dalam penelitian ini, dengan menggunakan nilai $r_{\text {tabel }}$ dengan jumlah sampel $(n=60)$ pada taraf signifikan $(5 \%=0,05)$ didapat nilai $r_{\text {tabel }} 0,250$. Nilai $r_{\text {hitung }}$ pada tiaptiap variabel bergerak antara 0.620 sampai dengan 0,892 menunjukkan bahwa $r_{\text {hitung }}>r_{\text {tabel. }}$. Dengan demikian, dapat disimpulkan bahwa alat ukur memiliki fungsi ukur yang sesuai atau memberikan alat 
ukur yang tepat untuk mengukur variabel bukti langsung / bukti fisik, kehandalan, daya tanggap, jaminan, empati dan kepuasan konsumen.

Sedangkan uji reliabilitas yang dapat dilihat dari nilai cronbach Alpha, reliabilitas yang baik adalah apabila nilai cronbach alpa makin mendekati 1,00. Berdasarkan uji reliabititas seperti terlihat pada Tabel 1, nilai Cronbach Alpha $(\alpha)$ lebih besar dari 0,60. Dapat disimpulkan bahwa setiap pertanyaan yang terkait dikatakan reliabel karena nilai alpha menunjukan cronbach alpha $>0,6$ hal ini menyatakan bahwa nilai reliabilitas dari bukti langsung / bukti fisik, kehandalan, daya tanggap, jaminan, empati dan kepuasan konsumen menunjukan hasil yang baik.

\section{Tabel 1 . Uji Reliabilitas}

\begin{tabular}{llll}
\hline No & Variabel & Alpha & Keterangan \\
\hline 1. & Bukti Fisik (X1) & 0,932 & Reliabel \\
2. & Kehandalan (X2) & 0,834 & Reliabel \\
3. & Daya Tanggap (X3) & 0,923 & Reliabel \\
4. & Jaminan (X4) & 0,898 & Reliabel \\
5. & Empati (X5) & 0,845 & Reliabel \\
6. & Kepuasan Konsumen (Y) & 0,944 & Reliabel \\
\hline
\end{tabular}

Sumber : Data primer diolah

Berdasarkan perhitungan regresi linier berganda antara variabel terikat dan variabel bebas dengan dibantu program SPSS dalam perhitungannya dapat dilihat seperti pada Tabel 2 sebagai berikut:

Tabel 2. Hasil Analisis Regresi Linier Berganda

\begin{tabular}{lrrrrc}
\hline \multirow{1}{*}{ Model } & Unstandardized Coefficients & \multicolumn{2}{c}{$\begin{array}{c}\text { Standardized } \\
\text { Coefficients }\end{array}$} & T & Sig. \\
& $\mathrm{B}$ & Std. Error & Beta & & .375 \\
\hline Bukti Fisik & .375 & .353 & 1.064 & .292 & .007 \\
Kehandalan & .319 & .113 & .327 & 2.818 & .116 \\
Daya Tanggap & -.225 & .141 & -.236 & -1.599 & .007 \\
Jaminan & .362 & .128 & .361 & 2.827 & .076 \\
Empati & .240 & .132 & .254 & 1.812 & .074 \\
\hline
\end{tabular}

Berdasarkan hasil analisa regresi linier berganda seperti terlihat pada Tabel 2, maka model persamaan regresi linier berganda dapat disusun sebagai berikut : $\mathrm{Y}=0,375+0,319 \mathrm{X} 1+-0,225 \mathrm{X} 2+0,362 \mathrm{X} 3+0,240 \mathrm{X} 4+0,215 \mathrm{X} 5+\mathrm{e}$

Berdasarkan persamaan regresi linier berganda tersebut, dapat diuraikan sebagai berikut:

1. Nilai konstanta a sebesar 0,375 menunjukkan bahwa jika bukti langsung / bukti fisik, keandalan, daya tanggap, jaminan dan empati diasumsikan tetap maka kepuasan konsumen akan bertambah sebesar 0,375 . Hal tersebut dikatakan logis, karena bukti langsung, keandalan, daya tanggap, jaminan, dan empati mempengaruhi kepuasan konsumen.

2. Variabel bukti langsung / bukti fisik memiliki koefisien regresi sebesar 0,319. Nilai tersebut menunjukkan bahwa terdapat hubungan positif antara dengan kepuasan konsumen yang berarti bahwa, bila bukti langsung / bukti fisik ditingkatkan maka nilai kepuasan konsumen pun akan meningkat sebesar 0,319 dimana variabel lain adalah tetap (konstan).

3. Variabel keandalan memiliki nilai koefisien sebesar -0,225. Hal ini menunjukkan bahwa bahwa terdapat hubungan negatif antara keandalan dengan kepuasan konsumen yang berarti bahwa, bila terjadi perubahan pada variabel keandalan, maka kepuasan konsumen akan menurun.

4. Variabel daya tanggap memiliki koefisien regresi sebesar 0,362 . Nilai tersebut menunjukkan bahwa terdapat hubungan positif antara daya tanggap dengan kepuasan konsumen yang berarti bahwa, bila daya tanggap ditingkatkan maka nilai kepuasan konsumen pun akan meningkat sebesar 0,362 dimana variabel lain adalah tetap (konstan).

5. Variabel jaminan memiliki koefisien regresi sebesar 0,240. Nilai tersebut menunjukkan bahwa terdapat hubungan positif antara jaminan dengan kepuasan konsumen yang berarti bahwa, bila 
jaminan ditingkatkan maka nilai kepuasan konsumen pun akan meningkat sebesar 0,240 dimana variabel lain adalah tetap (konstan).

6. Variabel empati memiliki koefisien regresi sebesar 0,215 . Hal tersebut menunjukkan bahwa terdapat hubungan positif antara empati dengan kepuasan konsumen dimana, bila empati ditingkatkan maka nilai kepuasan konsumen pun akan meningkat sebesar 0,215 dimana variabel lain adalah tetap (konstan).

Uji t digunakan untuk membuktikan pengaruh masing-masing atau secara parsialantara variabel bebas terhadap variabel terikat seperti terlihat pada Tabel 3 .

Tabel 3. Hasil Uji t (Parsial)

\begin{tabular}{lcl}
\hline Model & T & Sig. \\
\hline 1 (Constant) & 1.064 & .292 \\
Bukti Fisik & 2.818 & .007 \\
Kehandalan & -1.599 & .116 \\
Daya Tanggap & 2.827 & .007 \\
Jaminan & 1.812 & .076 \\
Empati & 1.820 & .074 \\
\hline
\end{tabular}

a. Dependent Variable: KEPUASAN KONSUMEN

Sumber : Data primer diolah

Dari hasil perhitungan nilai thitung untuk bukti langsung / bukti fisik adalah sebesar 1,064. Uji $t$ masing-masing dapat dilihat pada Tabel 3 yaitu pada nilai $\mathrm{T}$ dengan nilai $\mathrm{df}=\mathrm{n}-\mathrm{k}-1=60-5-1=54$ maka diperoleh $t_{\text {tabel }}$ sebesar 2,005 yang berarti bahwa nilai $t_{\text {hitung }}$ lebih besar dari tabel yaitu $2.818>2,005$. Nilai signifikansi 0,007 $<0,05(\alpha)$, menandakan variabel bukti langsung / bukti fisik secara parsial mempunyai pengaruh positif dan signifikan terhadap kepuasan konsumen. Dengan demikian dapat disimpulkan bahwa, variabel bukti langsung / bukti fisik mempunyai pengaruh yang positif terhadap kepuasan konsumen dapat diterima.

Dari hasil perhitungan diperoleh nilai $t_{\text {hitung }}$ untuk variabel keandalan adalah sebesar -1.599 diperoleh $t_{\text {tabel }}$ sebesar 2,005. Yang berarti bahwa nilai $t_{\text {hitung }}$ lebih besar dari $t_{\text {tabel }}$ yaitu $-1.599<2,005$. Nilai signifikansi 0,116>0,05 $(\alpha)$. Dengan demikian dapat disimpulkan, variabel keandalan secara parsial tidak mempunyai pengaruh signifikan terhadap kepuasan konsumen.

Dari hasil perhitungan nilai thitung untuk variabel daya tanggap adalah sebesar 2.827 diperoleh $t_{\text {tabel }}$ sebesar 2,005. Yang berarti bahwa nilai $t_{\text {hitung }}$ lebih besar dari $t_{\text {tabel }}$ yaitu $2.827>2,005$. Nilai signifikansi 0,007 $<0,05(\alpha)$, menandakan variabel daya tanggap secara partial mempunyai pengaruh positif dan signifikan terhadap kepuasan konsumen. Dengan demikian dapat disimpulkan bahwa variabel daya tanggap mempunyai pengaruh yang positif terhadap kepuasan konsumen dapat diterima.

Dari hasil perhitungan diperoleh nilai $t_{\text {hitung }}$ untuk variabel jaminan adalah sebesar 1,812 diperoleh $t_{\text {tabel }}$ sebesar 2,005, yang berarti bahwa nilai $t_{\text {hitung }}$ lebih besar dari $t_{\text {tabel }}$ yaitu $1,812<2,005$. Nilai signifikansi 0,076>0,05 $(\alpha)$. Dengan demikian dapat disimpulkan bahwa, variabel jaminan secara parsial tidak mempunyai pengaruh signifikan terhadap kepuasan konsumen.

Dari hasil perhitungan diperoleh nilai thitung untuk variabel empati adalah sebesar 1,820 diperoleh $t_{\text {tabel }}$ sebesar 2,005, yang berarti bahwa nilai $t_{\text {hitung }}$ lebih besar dari $t_{\text {tabel }}$ yaitu $1,820<2,005$. Nilai signifikansi 0,074 >0,05 $(\alpha)$. Dengan demikian dapat disimpulkan bahwa, variabel empati secara parsial tidak mempunyai pengaruh signifikan terhadap kepuasan konsumen di Laboratorium Klinik X Jakarta.

Dalam melakukan uji $\mathrm{F}$, parameter yang digunakan adalah dengan membandingkan $\mathrm{F}_{\text {hitung }}>\mathrm{F}_{\text {tabel. }}$. Pengujian terhadap pengaruh variabel bebas terhadap variabel terikat secara simultan dilakukan dengan uji F dengan hasil yang dapat dilihat pada Tabel 4.

Tabel 4. Hasil Uji F (Simultan)

\begin{tabular}{lrrrrl}
\hline Model & Sum of Squares & \multicolumn{1}{c}{ Df } & Mean Square & \multicolumn{1}{c}{ F } & Sig. \\
\hline Regression & 8.268 & 5 & 1.654 & 27.686 & $.000 \mathrm{a}$ \\
Residual & 3.225 & 54 & .060 & & \\
Total & 11.493 & 59 & & &
\end{tabular}


a. Predictors: (Constant), Empati, Bukti Fisik, Daya Tanggap, Jaminan Kepastian, Kehandalan

b. Dependent Variable: Kepuasan Konsumen

Sumber : Data primer diolah

Berdasarkan Tabel 4 menunjukkan hasil perhitungan uji $\mathrm{F}$ maka diperoleh nilai $\mathrm{F}_{\text {hitung }}$ sebesar 27,686 dengan menggunakan tingkat keyakinan 95\% dan tingkat signifikan 0,05 , df $=$ jumlah variabel bebas $=5$ dan df (n-k-1) atau 60-5-1= 54, hasil diperoleh untuk $\mathrm{F}_{\text {tabel }}$ sebesar 3,168. Pada Tabel 4 nilai $F_{\text {hitung }}>F_{\text {tabel }}(27,686>3,168)$ sehingga jelas Ho ditolak dan Ha diterima. Hal ini menunjukkan bahwa bukti langsung / bukti fisik, kehandalan, daya tanggap, jaminan dan empati berpengaruh secara simultan atau bersama-sama terhadap kepuasan konsumen di Laboratorium Klinik X Jakarta.

Tabel 5. Koefisien Determinasi (R2)

\begin{tabular}{lcccc}
\hline Model & $\mathbf{R}$ & R Square & Adjusted R Square & Std. Error of the Estimate \\
\hline 1 & $.848 \mathrm{a}$ & .719 & .693 & .24439 \\
\hline
\end{tabular}

a. Predictors: (Constant), Bukti Fisik, Daya Tanggap, Kehandalan, Jaminan, Empati

Sumber : Data primer diolah

Berdasarkan Tabel 5 tersebut, dapat diketahui bahwa besarnya nilai dari koefisien determinasi ditunjukkan oleh nilai Adjusted $R$ Square sebesar 0,693 atau 69,3\% yang artinya bahwa variasi dari semua variabel bebas yaitu bukti langsung / bukti fisik, kehandalan, daya tanggap, jaminan, dan empati dapat menerangkan variabel kepuasan konsumen sebesar 69,3\%, sedangkan sisanya sebesar 30,7\% dijelaskan oleh variabel lain diluar dari variabel penelitian ini seperti harga, promosi dan lain-lain.

\section{SIMPULAN DAN SARAN}

Berdasarkan hasil penelitian akan ditarik beberapa kesimpulan guna menjawab rumusan masalah, yaitu : 1) Variabel bukti langsung / bukti fisik memiliki pengaruh positif terhadap kepuasan konsumen. Hal tersebut dikarenakan Laboratorium Klinik X memiliki peralatan laboratorium yang lengkap, peralatan (gedung dan fasilitas pendukung) tertata rapi, pegawai berpenampilan sopan, juga ruang tunggu nyaman dan lokasi yang mudah dijangkau, 2) Variabel kehandalan tidak memiliki pengaruh positif terhadap kepuasan konsumen. Hal ini diduga bahwa konsumen Laboratorium Klinik Xtidak mementingkan pegawai kesehatan yang melayani tepat waktu, pegawai yang memberikan pelayanan yang baik, pegawai kesehatan yang memberikan informasi yang akurat dan terpercaya, 3) Variabel daya tanggap memiliki pengaruh positif terhadap kepuasan konsumen. Hal diduga bahwa pegawai Laboratorium Klinik Xbersedia membantu, melayani dengan cepat, memberikan informasi secara jelas dan mampu menangani masalah konsumen, 4) Variabel jaminan memiliki pengaruh positif terhadap kepuasan konsumen. Berdasarkan hasil penelitian, konsumen merasa petugas kesehatan mampu menetapkan diagnosa penyakit, pegawai mampu berkomunikasi dengan baik, dan memiliki pengetahuan terkait spesifikasi perawatan yang ada mempunyai pengaruh penting terhadap kepuasan konsumen, 5) Variabel empati memiliki pengaruh positif terhadap kepuasan konsumen. Hal menunjukkan pegawai Laboratorium Klinik $\mathrm{X}$ menunjukkan sikap ramah dan sopan, pegawai memberikan perhatian secara khusus dan dapat memahami keinginan serta kebutuhan konsumen, 6) Berdasarkan analisa regresi linier berganda, variabel daya tanggap merupakan variabel yang paling dominan mempengaruhi kepuasan pelanggan Laboratorium Klinik X, 7) Hasil perhitungan uji $F$ diperoleh nilai $F_{\text {hitung }}>F_{\text {tabel }}(27,686>3,168)$ sehingga jelas Ho ditolak dan Ha diterima. Hal ini menunjukkan bahwa bukti fisik, kehandalan, daya tanggap, jaminan, dan empati, berpengaruh positif dan signifikan secara simultan atau bersama-sama terhadap kepuasan konsumen di Laboratorium Klinik X Jakarta Pusat.

Berdasarkan kesimpulan diatas maka, saran yang dapat penulis berikan sebagai masukan kepada perusahaan Laboratorium Klinik X dalam upaya meningkatan kepuasan konsumen adalah sebagai berikut: 1) Pihak pengelola diharapkan untuk terus melakukan peningkatan kualitas pelayanan pada dimensi kehandalan yaitu dengan memberikan jasa sesuai dengan yang dijanjikan, akurat dan terpercaya. Misalnya, kemampuan pelayanan dalam memberikan pelayanan yang tepat waktu, 2) Pihak pengelola diharapkan untuk terus melakukan peningkatan kualitas pelayanan pada dimensi jaminan yaitu dengan meningkatkan kemampuan karyawan untuk menimbulkan keyakinan dan kepercayaan terhadap janji 
yang telah dikemukakan kepada konsumen. Contoh dalam hal ini antara lain pengetahuan dan keterampilan karyawan dalam menetapkan diagnosa, karyawan dapat berkomunikasi dengan baik, karyawan dapat memberikan kepercayaan kepada konsumen.

3) Pihak pengelola diharapkan untuk terus melakukan peningkatan kualitas pelayanan pada dimensi empati yaitu kesediaan karyawan untuk lebih peduli memberikan perhatian secara pribadi kepada pelanggan. Misalnya karyawan harus menempatkan diri sebagai pelanggan. Jika pelanggan mengeluh maka harus dicari solusi segera, agar selalu terjaga hubungan yang harmonis dengan menunjukkan rasa peduli yang tulus. Dengan cara perhatian yang diberikan para karyawan dalam melayani dan memberikan tanggapan atas keluhan konsumen.

\section{DAFTAR PUSTAKA}

Arikunto, Suharsimi. 2010. Manajeman Penelitian. Jakarta: Rineka Cipta

Azwar, Azrul. 1996. Pengantar Administrasi Kesehatan Edisi Ketiga. Tangerang: Binapura Aksara.

Depkes RI. 1998. Standar Pelayanan dan Asuhan Keperawatan di Rumah Sakit. Jakarta: Departemen Kesehatan RI.

Ghozali, Imam. 2013. Aplikasi Analisis Multivariate Dengan Program IBM SPSS 21. Semarang: Badan Penerbit Universitas Diponegoro.

Haryanto, Edy. 2013. Kualitas Layanan, Fasilitas dan Harga Pengaruhnya Terhadap Kepuasan Pengguna Jasa Layanan Pada Kantor Samsat Manado, Jurnal EMBA: Jurnal Riset Ekonomi, Manajemen, Bisnis dan Akuntansi Vol, No.3 September 2013: 750-760.

Kaihatu, Thomas Stefanus. 2008. Analisa Kesenjangan Kualitas Pelayanan dan Kepuasan Konsumen Pengunjung Plaza Tunjungan Surabaya. Jurnal Manajemen dan Kewirausahaan. Vol. 10. No 1. 66-84.

Kotler, Philip dan Kevin Lane Keller. 2015. Manajemen Pemasaran. Edisi 13 Belas. Jakarta: Erlangga.

Parasuraman, A. Valarie A. Zeithaml and Leonard L. Berry. 1988. SERVQUAL: A multiple-Item Scale for measuring Consumer Perceptions of Service Quality. 1988. Journal of Retailing. Vol. 64, (1). 12-40.

Prasetio, Ari. 2012. Pengaruh Kualitas Pelayanan dan Harga Terhadap Kepuasan Pelanggan Pada PT. TIKI Cabang Semarang. Management Analysis Journal. Vol 1 No. 1.1-7.

Ratminto \& Atik Septi Winarsih. 2010. Manajemen Pelayanan. Yogyakarta: Pustaka Pelajar.

Santoso, Singgih. 2010. Statistik Multivariat, Jakarta: PT Gramedia Pustaka Utama.

Sugiyono, 2015. Metode Penelitian Manajemen. Bandung: Alfabeta Bandung.

Tjiptono, Fandy dan Gregorius Chandra. 2012. Pemasaran Strategik. Yogyakarta: Andi.

Tjiptono, Fandy. 2014. Pemasaran Jasa - Prinsip, Penerapan, Penelitian. Yogyakarta: Andi. 